\title{
Coastal Tourism: Opportunity and Sustainability
}

\author{
Tuhin Ghosh (Corresponding Author) \\ School of Oceanographic Studies, Jadavpur University \\ Kolkata 700032, India \\ E-mail: tuhin_ghosh@yahoo.com
}

Received: August 29, 2011

Accepted: October 14, $2011 \quad$ Published: December 1, 2011

doi:10.5539/jsd.v4n6p67

URL: http://dx.doi.org/10.5539/jsd.v4n6p67

\begin{abstract}
Coasts provide some unique features for being an attractive place for the tourists. Different types of coasts according their own character offer variety of flavours to the tourists as the compound features produced from the triad of sun, sea, and sand are unique in nature. There are several problems in coastal tourism and associated activities along with the immense scope for developing a sustainable tourism with high return of investment. The economic growth and environmental destruction are the result of the conflicts between social and natural systems with the interplay of human activities. There is a need for proper approach with a holistic view to maintain the sustainability of coastal tourism, with the sustained economic growth from coastal tourism, as a potential sector.
\end{abstract}

Keywords: Coastal tourism, Problems, Sustainable strategy

\section{Introduction}

Tourism has become one of the most important industries on a global scale and expected to grow $100 \%$ over the next 10 years (Burke et al., 2001; World Travel \& Tourism Council, 2006; UN Atlas of the Ocean, 2004; Secretariat of the Convention on Biological Diversity, 2004; UNEP Division of Technology, Industry, and Economics, 2006). The industry already contributed around $10 \%$ of the total global Gross Domestic Product (GDP) of about USD $\$ 44$ trillion by the year 2006, and will increase to $10.9 \%$ by the year 2016 (Figure 1). Tourism shows its ability to fulfill the demand of $8.7 \%$ of total employment, or about 230 million jobs globally in 2006 with an expectation to create more 40 million jobs within 2016 (UN Atlas of the Ocean, 2004; World Travel \& Tourism Council, 2006).

In 2006 global scenario about the tourists is that they spent almost USD \$3 trillion on personal travel while USD $\$ 700$ billion on business travel. It is again estimated that the capital investment should increase from $9.3 \%$ to $9.6 \%$ by 2016 and globally the Government spending in 2006 of USD $\$ 300$ billion (equivalent to $3.8 \%$ of all government expenditures) on the tourism industry will reach at USD $\$ 200$ billion (equivalent to $4 \%$ of all Government spending) by the year 2016 (World Travel \& Tourism Council, 2006).

\section{Why Coastal Tourism?}

About $40 \%$ of the world's population lives on the coast or within the coastal zone (Burke et al., 2001) and they are dependant on the coastal tourism besides their other profession like fisheries, agriculture and so on. So, it is clear that tourism in the coastal regions is a significant way of earning. An interesting example of increasing interest in coastal tourism can be marked as global growth of whale watching diving certification has increased $12.1 \%$ annually since 1990 and the increased interest is 9 million between 1967 and 1990 (Garrod \& Wilson, 2003).

The realization of the importance of coastal tourism to the global economy, and the resulting impacts on coastal communities along with their physical, socio-economic and cultural environments has led towards sustainable tourism (Björk, 2000; Burke et al., 2001; European Commission Tourism Unit, 2000; Gill et al., 2003; Lee \& Moscardo, 2005; Mycoo, 2006; Sharpley, 2006; 2009; Spenceley, 2008). This thought process again accentuated by the increasing tourist demand for more responsible and environment friendly options (Dobson, 2003; Garrod \& Wilson, 2003; Mycoo, 2006; Sharpley, 2006). Coastal tourism is becoming more harmful for the fragile natural and cultural areas, as those areas are mostly preferred by the tourists (Gill et al., 2003; Kline, 2001; Briguglio \& Briguglio, 2000; Secretariat of the Convention on Biological Diversity, 2004; UNEP Division of Technology, Industry, and Economics, 2006; UN Atlas of the Ocean, 2004). 


\section{Problems of coastal tourism}

The impact of coastal tourism is manifold and delicate for the coastal community and their livelihood. The negative impacts on the coastal environments are resulted from the tremendous pressure on limited local resources, increased or unwanted invasion of natural areas and serious conflict between tourism and other sectors (Garrod \& Wilson, 2003; Dobson, 2003; UN Atlas of the Oceans, 2004).

The impact on water, food and energy resources are extreme as they are primarily for personal consumption and are heavily abused by tourists in hotel and food plaza along with excessive lighting and air cooling systems, swimming pools, golf courses, etc. (Gössling, 2002; UN Atlas of the Oceans, 2004). Local fish stocks can become severely threatened by tourists who wish to indulge on local cuisine, resulting market competition with the local community (UN Atlas of the Oceans, 2004). Water resource is certainly degraded qualitatively by pollution and quantity wise through over withdrawal and abuse. Often, the local sewage infrastructure has no such capacity to bear with the tourist population, particularly during the peak season for the tourists, and on the other hand it is also directly affected by cruise tourism producing an increased amount of waste and other pollutants (Burke et al., 2001; UN Atlas of the Oceans). Even widely campaigned so-called 'eco-cruises' are environmentally destructive as they entering into the highly sensitive ecological niche. Also they create cultural pollution, which is intangible and ignored so far. Water pollution, through time, produce eutrophic conditions and algal blooms, changes in salinity and siltation patterns, posing threats to plant and animal health, and undesirable aesthetics (Gössling, 2002; UN Atlas of the Oceans, 2004).

Land degradation and land-use change, results habitat and biodiversity loss, directly from the construction of tourist facilities and infrastructure through the clearing of mangroves, wetlands, and beaches, and the extraction of building materials (UN Atlas of the Oceans, 2004) or due to increased intrusion in the sensitive coastal ecology. A noteworthy example is the decreases in sea turtle nesting directly related to an increase of tourist flow along the nesting beaches (Schroeder, 2001).

In case of beach or shoreline tourism development, like construction of ports and resorts on the beach, the destruction of natural barriers and changes to sediment flow patterns, accentuates coastal erosion (UN Atlas of the Oceans, 2004). Unregulated and uncontrolled tourism construction is always primarily responsible for the destruction of aesthetic value of physical beauty of the coast and it always has a tendency to move closer to the water mark to create more attraction for tourists. Diving or snorkeling or engaging in other water-based activities are always responsible for coastal ecosystem and biodiversity loss, when tourists make their access to sensitive areas (Burke et al., 2001; Gössling, 2002; UN Atlas of the Oceans, 2004).

Tourism development with an increase in air travel for more convenience and mobility contributes to an increase in global carbon dioxide emissions and climate change resulting in sea-level rise and the loss of popular beaches like Maldives, Mauritius and Caribbean. Also, increased ground and water transportation can lead to severe local air pollution and acid rain has negative impact on health and environment (Gössling, 2002; UN Atlas of the Oceans, 2004). Noise pollution is another important result of increased air, ground, and water traffic that can lead to hearing problems and even deafness (UN Atlas of the Oceans, 2004).

The reality of economic gains from coastal tourism is established and the most real thing is the financial investment and profit is by and for the people outside the region, who are not only physically, also socially far removed from the area. The absence in equity in benefits within the local community may sometimes result in financial losses and increased local poverty (Kilne, 2001; UN Atlas of the Oceans, 2004; UNEP Division of Technology, Industry, and Economics, 2006). Thus, uncontrolled tourism development is a catalyst for environmental damage, and repair can cost local populations and government more than they would really gain from that industry (Kilne, 2001; UNEP Division of Technology, Industry, and Economics, 2006).

The global trend and reality is that tourism investors and developers create pressure on government to spend public money on improving infrastructure and services essential for the industry, promotion campaigns, including tax breaks and other financial incentives (UNEP Division of Technology, Industry, and Economics, 2006). Its true that the coastal tourism may result an increase in employment opportunities and that can be an economic benefit, even attracting job seekers from outside the local community. But in lean seasons and other tourism crisis can see mass scale unemployment leading to social consequences (UNEP Division of Technology, Industry and Economics, 2006).

During tourism development the supply and demand concept will force the cost of basic products and services and real estate to increase rendering them inaccessible to the local population resulting an increase in the cost of living (UNEP Division of Technology, Industry, and Economics, 2006). 
Influx of tourists can always alter the traditional culture of the local community to render vulnerable changes, posing risk to the loss of a community's structure and indigenous identity, intra-community conflicts between generations, genders, races, and classes, and can make local resources inaccessible to the native population (UN Atlas of the Oceans, 2004).

\section{Strategy for sustainable coastal tourism}

A sustainable strategy is necessary to formulate a sustainable coastal tourism management plan for mitigating the process of degradation of coastal community considering the physical environment, local economy and culture, and must include the local industries not related to the coastal tourism (Burke et al., 2001; Dobson, 2003; Garrod \& Wilson, 2003; Kline, 2001; Secretariat of the Convention on Biological Diversity, 2004; Yunis, 2006). There should be a holistic policy for sustainable development involving policy and decision makers, and developers and managers from GOs, NGOs, and other organisations, the private sector, and the local and native communities during formulation of a tourism development plan. There must be a balance between conservation and people, addressing the demand of the local community for easy access to necessary services and ability to manage their own natural resources, ensuring their livelihood and fair distribution of profit and resources including intercultural tolerance (Björk, 2000; Dobson, 2003; Garrod \& Wilson, 2003; Kline, 2001; Secretariat of the Convention on Biological Diversity, 2004; UNEP Division of Technology, Industry, and Economics, 2003; Yunis, 2006). Eventually, sustainable tourism is certainly a balance between the tourism industry and the local community to protect the destruction of assets on which the coastal tourism is really dependant (Burke et al., 2001; Dobson, 2003; Garrod \& Wilson, 2003).

\section{Major global initiatives}

There are several international conventions that affect the coastal tourism industry in an effort to make it a more sustainable venture. Some major ones include the United Nations Convention on the Law of the Sea (UNCLOS, 1982), Agenda 21, Convention on Biological Diversity (CBD), Convention Concerning the Protection of the World Cultural and Natural Heritage (World Heritage Convention), and, of particular interest to the cruise ship industry, the International Convention for the Prevention of Pollution from Ships (MARPOL 73/78). Others include conventions concerning climate change and other aspects of pollution (UBC Fisheries Centre, 2004). However, these agreements are only as affective as the signatories' abilities to ratify and enforce them, as there is often a gap between theory and practice (Garrod \& Wilson, 2003).

CBD, adopted at the Earth Summit in Rio de Janeiro, Brazil in 1992, outlines specific guidelines to establish a sustainable tourism industry. The overall goals of the convention are conservation of biodiversity, sustainable use of its components, and fair and equitable sharing of benefits arising from genetic resources (Secretariat of the Convention on Biological Diversity, 2004; UBC Fisheries Centre, 2004). The guidelines for sustainable tourism were adopted during the seventh meeting of the Conference of the Parties to the Convention on Biological Diversity in Kuala Lumpur, Malaysia in 2004. It covers policymaking, development planning, and management processes, proposal process and information requirements, and education, capacity-building, and awareness-raising as a tool for policy and decision makers and managers in a multi-stakeholder process for developing a sustainable tourism industry (Secretariat of the Convention on Biological Diversity, 2004).

\section{References}

Bixby, S., J. Page, J. Rielly, A. Rodreguez \& C. Good. (2001). The history \& future of cruise ship waste: modern perspectives for a changing industry. Sea Grant. Internet. [Online] Available: http://seagrant.uaf.edu (May 4, 2010)

Björk, P. (2000). Ecotourism from a conceptual prospective, an extended definition of a unique tourism form. International Journal of Tourism Research. 2 (3), 189-202. http://dx.doi.org/10.1002/(SICI)1522-1970(200005/06)2:3<189::AID-JTR195>3.0.CO;2-T

Briguglio, L. \& M. Briguglio. (2000). Sustainable tourism in islands and small states: case studies. London, UK: Cassell/Pinter.

Burke, L., Y. Kura, K. Kassem, C. Revenga, M. Spalding \& D. McAllister. (2001). Pilot analysis of global ecosystems: coastal ecosystems. Washington, DC, USA: World Resources Institute.

Dobson, S. (Ed.). (2003). Edited proceedings from the workshop "Policy Directions for Coastal Tourism". Burnaby, BC, Canada: Simon Fraser University.

European Commission Tourism Unit. (2000). Towards quality coastal tourism: integrated quality management (IQM) of coastal tourist destinations. Brussels, Belgium: European Commission. 
Garrod, B. \& J. C. Wilson (Eds.). (2003). Marine ecotourism: issues and experiences. Sydney, Australia: Channel View Publications.

Gill, A., D. Fennell, S. LeRoy \& R. Dobell (2003). Workshop backgrounders: 2003 OMRN national conference "Coastal Tourism". Halifax, NS, Canada: Ocean Management Research Network.

Gössling, S. (2002). Global environmental consequences of tourism. Global Environmental Change. 12, 283-302. http://dx.doi.org/10.1016/S0959-3780(02)00044-4

Klein, R. A. (2003). Cruising - out of control: the cruise industry, the environment, workers, and the Maritimes. Halifax, NS, Canada: Canadian Centre for Policy Alternatives.

Kline, J. D. (2001). Tourism and natural resource management: a general overview of research and issues. Washington, DC, USA: United States Department of Agriculture.

Lee, W. H. \& G. Moscardo. (2005). Understanding the impact of ecotourism resort experiences on tourists' environmental attitudes and behavioural intentions. Journal of Sustainable Tourism. 13 (6), 546-565. http://dx.doi.org/10.1080/09669580508668581

Mycoo, M. (2006). Sustainable tourism using regulations, market mechanisms and green certification: a case study of Barbados. Journal of Sustainable Tourism. 14 (5), 489, 511.

Robertsen, G. (2005). Cruise ship tourism industry. Lighthouse Foundation. Internet. Viewed on 3 May 2010. [Online] Available: http://www.lighthouse-foundation.org

Schroeder, B. A. (2001). Reducing threats at nesting beaches. In K.L. Eckert and F.A. Abreu (Eds.). Marine turtle conservation in the wider Caribbean Region: a dialogue for effective regional management. (pp 115-120). Santo Domingo, Dominican Republic: International Union for the Conservation of Nature.

Secretariat of the Convention on Biological Diversity. (2004). Guidelines on biodiversity and tourism development. Montreal, QC, Canada: Secretariat of the Convention on Biological Diversity.

Sharpley, R. (2006). Ecotourism: a consumption perspective. Journal of Ecotourism. 5 (1-2), 7-22. http://dx.doi.org/10.1080/14724040608668444

Sharpley, R. (2009). Tourism development and the environment:beyond sustainability? (pp. 220) USA: Earthscan.

Spenceley, A. (Ed.) (2008). Responsible Tourism (pp. 386). USA: Earthscan.

UBC Fisheries Centre. (17 November 2004). Treaties and conventions. University of British Columbia. [Online] Available: http://seaaroundus.org (May 3, 2010)

UN Atlas of the Oceans. (10 March 2004). Recreation and tourism. Online. United Nations Environment Programme. [Online] Available: http://www.oceansatlas.org (May 4, 2010)

UNEP Division of Technology, Industry, and Economics. (09 January 2006). Sustainable development of tourism. Online. United Nations Environment Programme. [Online] Available: http://www.uneptie.org. (May 4, 2010)

UNEP Division of Technology, Industry, and Economics. (7 February 2003). About ecotourism. United Nations Environment Programme. [Online] Available: http://www.uneptie.org (May 3, 2010)

Wheat, S. (06 September 2004). Ecotourism - hope and reality. People \& the Planet. [Online] Available: http://www.peopleandplanet.net (May 4, 2010)

World Travel \& Tourism Council. (2006). League tables: travel and tourism climbing to new heights: the 2006 travel \& tourism economic research. London, UK: World Travel \& Tourism Council.

Yunis, E. (2006). Tourism in SIDS: a key factor for economic, social and environmental sustainability. London, UK: World Tourism Organization. 


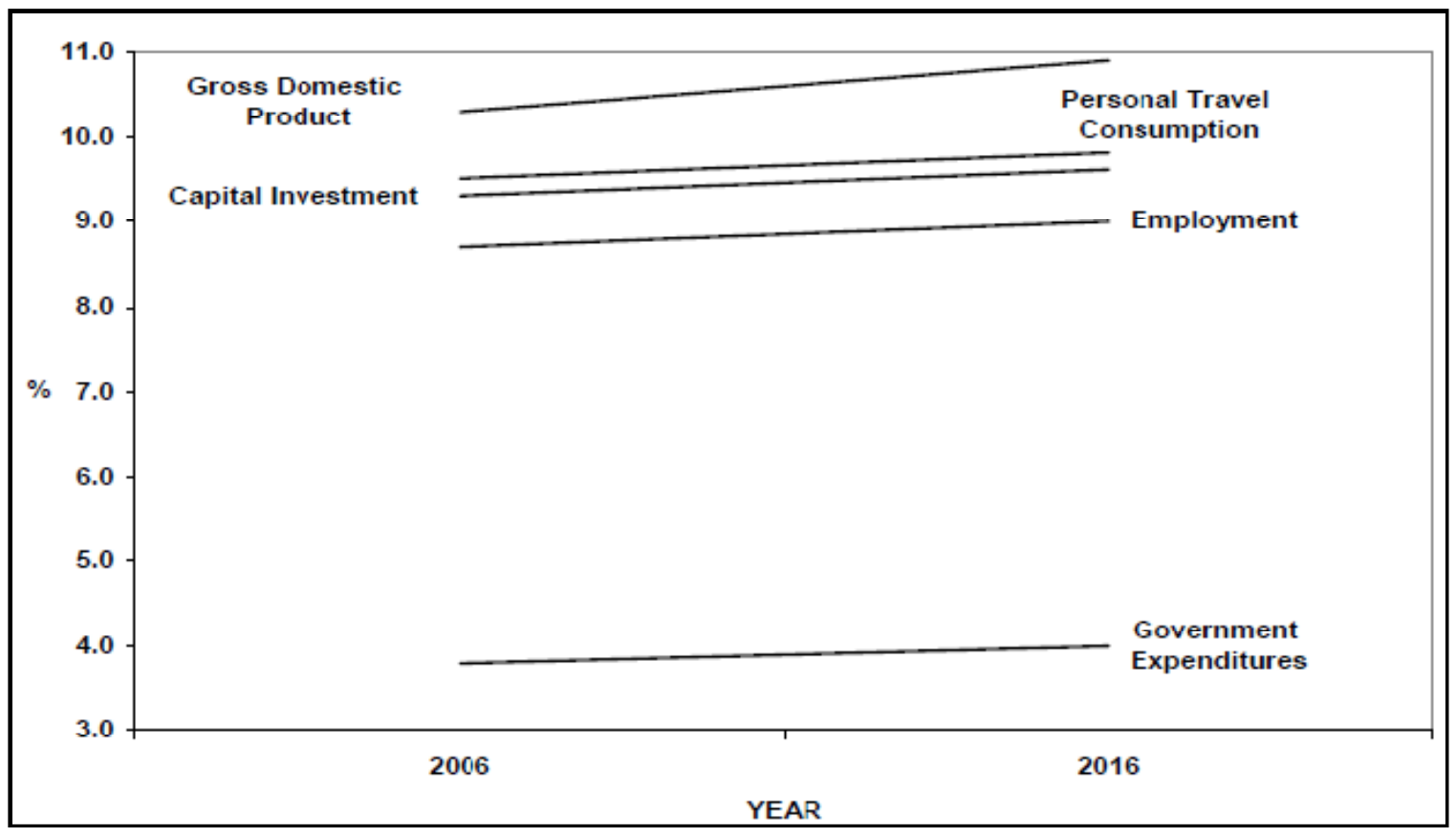

Figure 1. Growth trend of global tourism during 2006 - 2016

Source: World Travel \& Tourism Council, 2006 